\title{
Whatever happened to Italy? The Crisis of the Italian Pattern of Development in the Era of Globalization
}

\author{
By Domenico Maddaloni*
}

The paper presents a political economy approach, aimed at achieving a better understanding of macro social change, with special reference to the case of contemporary Italy. The political economy framework outlined in the paper stresses the systemic nature of societal processes, starting from the changes occurring in economic activities, the division of labor, and class and regional forces in the aftermath of World War II. In this context, the public sector and, in particular, the class of political entrepreneurs and mediators has played a key role in the rise and the incipient demise of the Italian pattern of development. Finally, as far as the cultural sphere is concerned, the model outlined here focuses on religion and mass media as other relevant factors in a success story, which is now turning into decline.

Keywords: Crisis, Globalization, Italy, Social change.

\section{Introduction}

In recent years, a growing awareness of an "Italian crisis" - viewed not just as a matter of business cycle, but as a systemic issue involving every dimension of national life - has spread both in the public opinion and in different communities of social scientists. Although the books on this topic date back to the late 1970s (see for instance Graziano and Tarrow 1979), the public debate on the Italian crisis became generalized in the late 1990s. Since then, the scholarly literature on the issue has been increasing, with growing number of historians, economists and social scientists taking part in this debate. A recurrent argument by many scholars is that the Italian crisis is not simply determined by the recent changes in the world economy - globalization and financialization (although it is certainly dependent on these) (see for instance Schiavone 1998, Ruffolo 2009, Gallino 2006).

The purpose of this paper is to investigate the economic, social and cultural changes that have turned the Italian model of development into a story of economic decline, social fragmentation and political Bonapartism, as it can be described these days. In order to explain such societal change, I employ a political economy approach, that will include the domains of economy and politics in a single framework, and to show the underlying configuration of material interests and dynamics of power that allow us to understand the behavior of the social actors (Staniland 1985, Mosco 2009: 1-126).

This perspective is quite different from "orthodox", or "old", political

${ }^{*}$ Professor of Sociology, University of Salerno, Italy. 
economy, mostly based on historical materialism, in two important aspects. First, the concept of political class (Mosca 1994), as an actor promoting their own interests, because of their ability to control public resources, is important. My opinion is that the economic, social and cultural changes seem to have produced, since the 1970s and even more so since the 1990s, a growing separation between this political class and civil society, or the electoral body to whom this class makes formal reference. We are now facing a world in which strategic collective choices - such as reducing the public budget - are viewed as "inevitable" by almost all parties - "Europe" wants this, "the markets" want that, and "there is no alternative". Moreover, the direct and active participation of citizens has been replaced in part by media communication. The idea of parties (or party coalitions) selecting the political staff and organizing the social demands along different cleavage lines (Lipset and Rokkan 1967, Karvonen and Kuhnle 2001) is rapidly losing meaning (Crouch 2003). Rather, it is more like a group, or a network, of political mediators, variously related to different fractions of the business world and the professions, which from time to time assume the role of rulers and opposition, center-right and center-left, but basically defend the same interests and share the same worldview. This process is now at work in all countries and at a global level (Sklair 2001). In Italy, however, the split between the political class and the civil society has always been intertwined with others at stake in the social life of the country particularly those between North and South (Mezzogiorno), capital and labor, autonomous and dependent workers, the public and private sector, the State and Church. Moreover, it increasingly and openly effects the political agenda of this same group, with the collusion of wide and important sectors of an entrepreneurial world, whose levels of collusion with the political class increases, despite the rhetoric of laissez faire.

Secondly, "superstructural" issues, such as the role of cultural institutions and trends in the process of social change, deserve attention. These issues refer to the role of religion - especially the Catholic Church - and the mass media in the social and political life of the country. Whilst there is no doubt about the great importance of the Catholic religion in Italy, it might be appropriate to say something about the role of mass media in a model of political economy whose purpose is to explain the development and decline of a social formation. In particular, as noted by Mosco (2009: 127-156), the growth and the commodification of the system of mass communication has substantially changed the role of communication itself in the production of (short-term) consensus and (long-term) hegemony of the privileged classes. This cultural sub-system has therefore suffered the same fate of the great religions - such as Catholicism - allies of political authority in trying to maintain the stability of the social order in their own interest.

An Italian pattern of development can be identified as an institutional setting aimed at combining the needs of capital accumulation with those of the social regulation of the economy and the political legitimacy of the system as a whole. Accordingly, this development model - partly drawing from the French regulation school (for an evaluation see Vitale 1998: 23-44) - can be 
analytically distinguished in an accumulation regime, a mode of regulation and a system of legitimacy. With the help of past and recent literature on the "Italian case", the focus will be on the transformations occurring in each of these dimensions of the Italian social formation.

\section{The Rise and Incipient Decline of the Italian Accumulation Regime}

Today Italy is not a poor country. In the period since World War II, the Italian economic system has reached high levels of production and income, thus ensuring an enormous growth in the standard of living and in the quality of life. The international position of the country in the international division of labor has, therefore, provided considerable returns in terms of welfare - for example, in terms of life expectancy and health status of the population, even if with persistent social inequalities (Sabbadini 2012). This also explains why, in the aftermath of World War II, Italy has been transformed from a country of emigration to one of immigration (Pugliese 2006). Nevertheless, the Italian model of development, partly shared by other Southern European countries (Sapelli 1996, Maddaloni 2008), has some rather unusual features.

First, until the 1970s the State, namely the political class of government ${ }^{1}$, made up for the scarcity of large private enterprises through the development of a State-owned industrial network (partecipazioni statali). However, the entrepreneurial class succeeded in pursuing their interests in the core sectors of the economy. For example, the State promoted a wave of investments in transport infrastructure which, between the 1950s and the 1970s, fostered car ownership at the expense of public transport, thus widening the market for these industries.

Secondly, the development of modern industry occurred in a context marked by the primacy of family capitalism (a model followed even by the largest private industry). Family capitalism fosters small business and hides the social and environmental costs of production (Maddaloni 2000), with a widespread use of the informal economy and irregular work, or - in the industry of construction - illegal building activities in large part of the territory, especially in the South (Pizzorno 1980).

When this was not sufficient, particularly in the sectors exposed to international competition, the political class of government acted with policies of currency devaluation, which often imported inflation at the expense of employees' incomes, but also restored the necessary competitiveness of Italian business.

Thus, until the 1970s, there was a widespread political tolerance for

\footnotetext{
${ }^{1}$ If we look at the years between the 1940 s and the 1970 s, it could be reasonable to distinguish between the political class of government and that in opposition, which in those years was excluded/auto-excluded by the national government because of its proclaimed antisystem ideological vocation. In addition, between the 1940s and the 1970 s political participation was a mass phenomenon in Italy like in many other (capitalist democratic) advanced societies (Crouch 2003). These phenomena apparently prevented the political class to merge into a single block of interests separate from civil society.
} 
irregular behavior of entrepreneurs, and a national monetary policy based on devaluation and inflation. In addition, there was a decentralization of production outside Northwestern Italy, and accumulation of capital and entrepreneurial skills in the framework of family capitalism. These factors can explain the development of small business, which since the 1960s have spread in the regions of the North East and the Centre (Bagnasco 1977: 113-212).

In some sectors, however, Italian business gained a leading position. This is especially true for the food industry, for textiles, clothing and footwear, for some branches of the mechanical industry, and for the tourism sector. These economic sectors were therefore known as the Made in Italy, which is still today reputed as a special mark of quality (Bertoli and Resciniti 2012).

Finally, the so-called Italian "economic miracle" was also favored by the expansion of the internal market. This occurred because of changes in the structure of employment, as the Italian labor force moved from agriculture to industry and services. This also compensated for the negative effects of inflation on wages and salaries.

An important component of this process was the growth of the middle classes, and above all of public employment. The latter, occurring with a similar pace in the whole country, resulted in a greater role of public institutions as employers in the South. The growth in public employment, the expansion of capital expenditure in the public industry, the incentives granted to private investment in Southern Italy, and the policy of public works and infrastructure were the key factors of structural change in the Southern economy. Unlike what happened in other regions of the country, in fact, in the latter the development of small business was - and still is - narrower and frailer, and, therefore, more dependent on public resources (Bagnasco 1977: 33-111, Trigilia 1992).

The Italian regime of accumulation was based on several imbalances, which were more serious in Southern Italy (Barbagallo 1994). The presence of medium enterprises was weak, caught as it was between the State-owned or variously subsidized and protected large companies and the proliferation of small industries, craft workshops and self-employment in the service sector. In turn, the success of small business was largely due to the policy of tolerance against tax evasion, but also to non-compliance with the legislation on working conditions, environmental protection, and urban development (Pizzorno 1980). The fact that the fortunes of the entrepreneurs and the self-employed derived in part from a-legal or illegal behavior, reduced incentives favoring trust and honesty in business (Gerschenkron 1965), and made the emergence of "cartels" and monopoly rents easier.

The consent of public servants was purchased at the price of disorganization in public offices (Ginsborg 1998: 409-413). This seems to be an effect of two main causes: recruitment and career benefits for the unskilled but politically loyal, and collusion between the public employee unions and political leaders in the distribution of positions and benefits (Ichino 2006). In addition, a number of privileges relating to working conditions and social security benefits differentiated public employees from private workers, with 
distorting effects on the labor market (Gorrieri 1972, Pizzorno 1980, Ferrera 1984, Ascoli 1984).

Finally, the reduced ability of analysis and intervention of the central and local governments, and the permeability of the political class of government to interest groups (Dente 1990), hindered the development of policies supporting the most advanced economic sectors and the regional and social cohesion. This inability has gradually pushed the country into a secondary position in the international division of labor (Gallino 2003), and has prevented the reduction of territorial imbalances, the widest in Europe today.

Nevertheless, the pattern in question worked. Italy largely took advantage of the global economic recovery after World War II, and since the 1970s has entered the exclusive club of the world's richest nations.

From the late 1960s and early 1990s, the regime of accumulation I have briefly outlined here has been losing its constitutive elements. The achievement of full employment in the late 1960s led to widespread unrest, which formed the social base of terrorist groups active in Italy until the 1980s (Galli 1986, Lazar and Matard-Bonucci 2010). Furthermore, this widespread social unrest led to waves of trade unions micro disputes, particularly acute in the public sector and especially in State holdings (Ichino 2005). This resulted in a further boost to the decentralization of production, and after 1989 to the relocation towards Eastern Europe and emerging countries.

At the same time, this may have exacerbated the Italian bourgeoisie's trend of avoiding the visibility ensured by the large sized firm and taking refuge in monopoly and rent seeking if possible. The growing constraints imposed on public budgets by the European integration process fostered a crisis in the system of public-owned enterprises - the sector most affected also by the growth of labor unrest in the 1970s -, whose role as a propeller of regional cohesion and economic innovation could no longer be maintained. The economic recovery in the 1980 s allowed the Italian political and economic establishment to go ahead without large adjustments for some time - as Bettino Craxi, a major politician in the 1980 s, used to say, "... and the ship goes! " (Ginsborg 1998: 257-337). Nevertheless, in the early 1990s the change was inevitable, with the adhesion to the process leading to the European Monetary Union, the end of the season of competitive devaluations and the launch of a strict fiscal policy, preventing the growth of employment in the public sector and producing the privatization of most of the State holdings. Moreover, economic globalization produced further problems to Italian small business, especially in terms of competition on the prices from the emerging economies. Maybe the idea of a substantial disappearance of industry in Italy (Gallino 2003) is excessive, especially when referring to medium-sized and small business, and to the Made in Italy, but there is no doubt that the Italian regime of accumulation was fairly disrupted by these changes. Since the early the 90s, Italy has always had the lowest economic growth rates in the European Union.

In this context, marked by the ongoing inability of the State to support the recovery of the Italian economy, the response of most of the business system to the challenges of an increasingly fierce international competition can be 
likened to the move of castling in the chess game.

In a territorial perspective, it is no longer viable to support the Southern economy. Therefore, the castling takes the form of a conversion to the ideology of territorial discrimination, with a growing redistribution of resources to the benefit of the more developed regions (Maddaloni 2009, Viesti 2009). The latter host the (numerically and politically) most important part of the professional and entrepreneurial world; moreover, these regions elect the majority of the members of the national political class (MPs, political leaders, etc. $)^{2}$. Another aspect of this move is the push for flexibility in the use of the workforce to regain global competitiveness on the side of labor costs - despite its having counterproductive effects, in terms of depression of the domestic market, growth of job and life insecurity (Toscano 2007), and stagnation in labor productivity (Mania 2013, see also Ciccarone and Saltari 2015) ${ }^{3}$. Thirdly, there is a gradual restructuring of the fiscal policy in a regressive direction lower taxes on private wealth and luxury consumption, higher taxes on work income and ordinary consumption (Eurostat 2014). Pressures to privatization are equally important. This is what happens in the field of public industry, including the public utilities, from highways to public transport, from garbage collection to aqueducts. This happens also in social services, with the help of the rhetoric of federalism, the New Public Management and subsidiarity. In this way, the castling move results in the acquisition of monopoly rents in the public sector, thanks to privileged relations with the political class. The latter, therefore, regains the centrality seemingly lost with the disappearance of state holdings and the growing restrictions on the deficit growth.

The last element of the castling move is the endless reforms of the legal system and judicial procedures, which seem to occupy a significant portion of the working time both of the government and the Parliament (Openpolis Organization 2011). The Italian national political class largely neglects the issues of civil justice, which affect the ordinary citizens and economic actors, i. e. those not guaranteed by the means of a "special relationship" with politicians, public managers or criminal enterprises. Instead, it turns its attention to reforming the law and criminal procedure, and the relationship between the order of judiciary and executive power. In this political climate, the protection of the politician investigated, sometimes sentenced, by means of his / her re-election or "recycling" to another public agency - where he / she

\footnotetext{
2 The last financial programming document approved by the Italian government (September 2015) makes no substantial reference to the development of the Southern regions (source: A Pitoni, G Velardi, Mezzogiorno, nota di aggiornamento al Def: Così Renzi ha dimenticato il Sud. Retrieved from http://bit.ly/1g7Vt5X. [Accessed September 26, 2015]). This happens only a few weeks after an independent research center on the South reported that, since 2000, the growth performance of the Southern regions has been the worst in the European Union (SVIMEZ 2015).

${ }^{3}$ The process of reform of the labor market, which started in the 1980 s, recently has come to a turning point with the law No. 183 of 2014, known as "the Jobs Act", whose effects remain controversial. Like in other countries, the whole process is driven by the (empirically ineffective) idea that labor flexibility is the key to full employment and a rapid economic growth (Maddaloni 1998, 2004, Pini and Leonardi, 2015).
} 
can continue to spend his / her capital of licit and illicit relationships - seems to be a standard practice for the Italian political class (Vannucci 2012, 2013) ${ }^{4}$.

Moreover, this protects the collusion between the political class and a large part of the Italian bourgeoisie (Mania 2013), which, under the name of "civil society", more and more frequently takes on the direct management of political offices, thus creating a symbiosis between these groups. Not surprisingly, the "conflict of interests" - or the "clan rule" (McCarthy 1995: 167-191) becomes an increasingly common feature of the relationship between the political class and the business world, intrinsically inherent to the process of accumulation of wealth in which these strata are involved today.

\section{The Rise and Incipient Decline of the Italian Mode of Regulation}

The second postwar period was also a time of great mobility for Italian families. There was geographical mobility, especially from the South to the North-Centre, and a process of urbanization in the whole country. There was also social mobility, because of the changes in the structure of employment, induced by industrial and tertiary growth. Although often mobility has been "short-range" (Schizzerotto 2002), the association among this phenomena, the overall income growth and processes of economic and social modernization produced a widespread perception of material and civilian progress - a perception fueled by the access to the world of mass consumption and, in some social strata, even of luxury consumption. Moreover, this also produced the expectation that the Italian standard of living would have continued to grow, following the general modernization and development of the society.

Since the 1970s, there was a gradual slowdown of these processes, in Italy as well as in other advanced, "post-industrial" societies. The feeling of being part of the "marching column" (Hirsch 1977) towards new goals gave way, in an ever wider strata, to a revolution of diminishing expectations (Lasch 1979), and the metaphor of the march towards a better future for everyone gave way to that of the "stalling of the social elevator" (Nicoletta 2013). It is true that, since the 1990s, there was a resumption of the internal mobility of the population, but this is due to the negative conditions in which the Southern Italian economy has fallen due to the decline in public investment and the growth of unemployment in these regions (Bubbico et al. 2013, Bonifazi 2013). It is also true that, since the 1990s, there has been a general increase of employment rates in the whole country ${ }^{5}$, but this in turn is due to the so-called "atypical jobs" (see above, section 1). In fact, labor flexibility was, and still is, greatly encouraged by an economic policy inspired by the neoliberal ideological belief that the lack of development derived from the "rigidity" of

\footnotetext{
${ }^{4}$ The Italian Parliament has recently (2012 and 2015) adopted two anti-corruption laws, but the effects of these policies are highly controversial.

${ }^{5}$ This also happened in the Southern part of the country. The parallel growth of employment and unemployment is a phenomenon induced by the increase in the activity rate of the population.
} 
the labor market. Therefore, this development has little impact on the stability of employment and income levels (CNEL 2014), particularly for young people and the southern regions - to the point that the whole country is now facing a growing flux of emigration, involving people of every social and educational condition (Santoro 2015).

Since the 1990s, then, the cake is no longer growing and larger and larger shares of it are going to profits and rents for the benefit of a minority. What happens, then to young Italians who are experiencing the closing, or the reduction, of the channels of economic success and social mobility? They seek a new path of inclusion through the so-called "personal capitalism" (Bonomi and Rullani 2005). At a lower level in the social hierarchy, the path is defined by the "self-employment of the second generation" (Bologna and Fumagalli 1997). At the lowest level, they have no choice but to take refuge into "the art of getting by" (mainly in the Southern regions).

The spread of these figures, especially those of the self-employed and semi-autonomous worker, makes the distinction between the autonomous and dependent work elusive. Many hybrid forms emerge, sometimes sharing the opportunities, more often the risks arising from business, or from changes in local governments (the main source of non-standard employment is the public administration), or the favor of the politician or the official who has control over the activity.

Furthermore, these social figures are not easily suitable to recruitment and organization by the trade unions. Indeed, they seem to be caught among the desire to emulate those who are "above"; conflicting relationships with those who perform similar or identical tasks, but as fully guaranteed workers; and the fear of falling into unemployment. This social layer thus joins those of the employees and adjutants in small businesses and the irregular and / or occasional workers - the segments traditionally unsecured (Paci 1982, 1992) to form an even wider area of workers which are unrelated to the everdeclining (Crouch 2012) Fordist model of industrial relations, and, in addition, poorly protected by the Italian welfare system. The latter passed through a general process of reform, which intensified during the '90 (Pugliese 2004), and a further acceleration in recent years. However, the whole process can be described as a case of retrenchment without recalibration, with no substantial correction of its traditional imbalances. Therefore, today an ever-larger part of the Italian population - including migrants, and particularly in the South seems to be scarcely protected (Ascolin and Pavolini 2012).

As regards to the guaranteed layers, the decline of the Italian regime of accumulation is not devoid of effects on them too. The growing constraints on public spending reduce the benefits related to the status of civil servant. The retrenchment of State holdings, the relocation abroad of part of the industrial apparatus and the poor foreign investment flows - because of diseconomies imposed by public inefficiency, commercial dishonesty, and the spread of criminal entrepreneurship in several regions - result in a growing pressure on working and wage conditions of employees and workers in the private sector. This is especially true for the season of the "expansive austerity", triggered by 
the 2007-2009 crisis (Ciccarone and Saltari 2015).

Finally, as far as traditional self-employed workers are concerned, the competition unleashed by globalization of agricultural markets is worsening the working conditions and the income of farmers, while deregulation in retail is producing negative effects in the small retail trade. In addition, a more severe fiscal policy (for instance, on the side of the pension system) is reducing the work incomes of many autonomous workers, including the younger professionals. Therefore, while a part of the self-employed has continued to improve their standard of living, at least in relation to employees and the working class, another part faces growing risks of unemployment and impoverishment (Ranci 2012). This results in the appearance of an anti-civic attitude (Colloca 2015), not only towards the political class, but also towards other categories. Moreover, this disputing attitude is nourished by the regional imbalances, and - more recently - also by international migration and the presence of foreigners in the labor market, housing market and social services.

In this context, marked by growing social tensions, the political class, no longer divided into two opposing fractions as it was in the heydays of the Italian pattern of development, seems to acquire higher degrees of freedom. It is true that in no other developed country the party system has experienced a collapse similar to that in Italy between 1992 and 1994 (Bull 2012). Nevertheless, the vanishing of "modern" mass parties quickly gave rise to the emergence of a political class, la casta (Ciliberto 2015), which seems to hide behind every changing party name ${ }^{6}$. This major change starts from the crisis of antisystemic ideologies and movements. The systemic alternative to democratic capitalism given by the "socialist bloc" on an international level, and the Communist Party in domestic politics, disappeared in the ' 80 , and this seems to have had two major effects on the Italian social and political dynamics.

On the one hand, the social forces previously oriented towards collective action flow in two directions. The first lies in the move from a widespread interest in collective mobility to an even wider and stronger interest in individual mobility. Given the conditions of economic stagnation this results, especially in the South, in lower inhibitions towards a growing subordinate inclusion in national and local structures of power (clientelism, corruption, indirect or direct participation in associations among politicians, businessmen, mafia criminals) (Maddaloni 1993, see also Ginsborg 1998: 338-401). The second lies in the transition from political participation to commitment in voluntary nonprofit associations. This process has occurred both in Southern Italy (Trigilia 1995), and (more intensely) in the Northern and Central regions of the country (Istat 1999). At the same time, the nonprofit sector also develops a growing internal complexity and increases, through the co-management of welfare policies, its links with the political system (Salvini 2012: 43-68).

On the other hand, this leads to a crisis in the recruitment and selection of the political class of opposition, which previously consisted of officials of the Communist Party or its flanking organizations (cooperatives, trade unions,

\footnotetext{
${ }^{6}$ It is worth noting that a recent estimate of those involved in politics (lato sensu) calculates the number to be over a million, more than 5\% of total employment (Bagnasco 2015).
} 
cultural or leisure associations, etc.). The solution to this crisis was found in the opening towards the "civil society". However, this opening led to an increasing participation of entrepreneurs and professionals in the political arena (Maddaloni 2003) - the same layers from which the political class of government comes. Another source of recruitment and selection of the political staff is given by the officials of public agencies, which are used to present themselves as mediators between the interests affected by public policies. In the case of entrepreneurs or professionals "on loan to politics", the conflict of interest is realized through the private-public-private circuit (the economic power leads to political authority, which is used to increase the economic power). In the case of public officials, it consists in privileged access to administrative procedures and the benefits provided by public bodies. The result is a convergence in the views and the political agenda of the parties, which helps to explain the continuity in the path of institutional change, particularly with regard to welfare reform and fiscal policy, privatization and federalism, despite frequent changes in the government coalition. Journalistic inquiries (see, for instance, Stella and Rizzo 2007, Rizzo and Stella 2008) provide huge evidence of the convergence of the political class, at a national as well as local level, around a legislative or administrative practice that aims at increasing privileges and benefits for them ${ }^{7}$. Therefore, entrepreneurs and professionals have strong incentives to join this political class or to associate themselves with it, rather than face the challenge of competition and seek opportunities for economic success away from the rent ensured by political protection (Mania 2013).

Nevertheless, the Italian economic and social crisis is deepening. Job insecurity and unemployment increase, and the impoverishment of the working classes and the middle classes spreads, not only in the South (Secondulfo 2013). In addition, the awareness of being cut off from effective participation in social and political life of the country rises in many social strata, especially in those committed to addressing the challenges of innovation, competition and market globalization. The result was a new political earthquake in the general elections of 2013, with the sudden emergence of a new anti-systemic movement, the Movimento 5 Stelle (5 Star Movement) ${ }^{8}$. Not entirely framed in the usual logic of confrontation between right and left, the Movimento proposes innovative forms of political participation, especially involving young people (Biorcio and Natale 2013, Biorcio 2015b, Biorcio 2015a). The response of the political class to these pressures has twofold. There has been a change in leadership, from Silvio Berlusconi to the younger Matteo Renzi, a "leftist Berlusconi" (Bordignon, 2014). There has been also, more recently, a new attempt to institutional reform aimed at locking down the power of the political

\footnotetext{
${ }^{7}$ Other journalistic inquiries (see for instance Livadiotti 2008) show that this collection of privileges and benefits has spread to the body of the (major) trade union officials, thus creating a substantial divergence of interest between them and the workers who they are supposed to represent.

${ }^{8}$ The special nature of this movement can be highlighted by the meaning of the 5 stars of its name: public water, sustainable mobility, local development, Internet connectivity, environmental protection.
} 
class and its allies, by reducing the possibility of electoral choice and placing parliamentary activity under government control ${ }^{9}$. At present (October 2015), this attempt is still under way, and its outcome is uncertain.

\section{Cultural Changes and the Role of Cultural Institutions in the Italian Decline}

The last element explaining the rise and decline of the Italian development pattern after World War II relates to cultural changes. In this respect, it is possible to note, first, that the growth of material well-being was also followed by a significant increase in the levels of education. This change led to a widespread secularization (Sciolla 2015), which since the 1960s has involved religious practice and individual behavior, and since the 1980s seem to have had a role in the crisis of secular ideologies which have conveyed social inclusion and political participation of the masses. These processes, however, occur in a context marked by a persistent cultural backwardness in relation to European countries with a similar level of development (De Mauro, 2004). A backwardness that is not yet completely erased, because of the weakness that the entrepreneurial class and the public institutions show in supporting the labor demand for high qualification jobs, the only factor that could effectively foster individual commitment in education and training (Sciolla 2012).

A large part of the Italian entrepreneurial world tries to protect itself from the competition through collusion or osmosis with the political class, and therefore they need more "public relations" than high quality work. Another part of it faces the challenges of market competition trying more cost containment than research and development, particularly in technologically maturing sectors (this is true, in particular, for large part of the Made in Italy). In addition, the small size of businesses favors - in Italy more than in other advanced countries - the intergenerational transmission of the main entrepreneurial / managerial roles, rather than the use of professional skills and abilities unrelated to family capitalism (Bianco et al. 2012). Finally, as for the public sector, in the heydays of public employment, the recruitment and careers of the administrative and technical staff were affected by party membership and patronage, although in varying degrees this depended on places and areas of intervention. From 1993 onwards, instead, the employment policy in the public sector has been subject to restrictions, leading to a growing use of

\footnotetext{
${ }^{9}$ In line with a long tradition of policy analysis, many scholars use the category of "populism" to describe every recent innovation in the Italian political arena - Berlusconi's Forza Italia, Bossi's Northern League, Renzi's Democratic Party and, last but not least, the 5 Star Movement (see for instance Biorcio, 2015a). It is one thing, however, to adopt a populist rhetoric aiming to achieve a short-term electoral support, in order to preserve the privileges of the political class and the social forces close to it. Quite another is a continuous search for innovative forms of political participation and a systematic challenge to the claims of those who have the power. Perhaps this confusion highlights the difficulty of using frameworks inherited from the industrial / Fordist society to understand phenomena distinctive of a new era.
} 
technical and administrative staff in a regime of labor flexibility and job precariousness. Therefore, young people especially are forced more and more often to choose whether to stay and be part of the so-called "1000 Euros generation", or to emigrate in order to enhance their abilities and professional skills ${ }^{10}$.

In this context, it is possible to understand the persistence of the familism ${ }^{11}$ in Italian society as an orientation to the action that pursues individual wellbeing through the mobilization of kinship networks. The Italian development after World War II resulted in a deep change in the relationship between the individual and his kinship network. If, in the past, the needs of reproduction of the latter prevailed on individual expectations, since the 70s there has been a sharp turnaround, even in an underdeveloped region as Calabria (Piselli 1981). The family is now at the service of its members, helping them in the search for employment opportunities, a home, or care services (Bagnasco 1996: 53-60, Saraceno 2015: 399-421).

The Italian political class has used this trend to their advantage in order to "recalibrate" social and educational policies. Italian political entrepreneurs have always used familism in the making of a rhetoric of family values that should be protected from the interference of the State (Ginsborg 1989: 233237). By doing this, they achieve a saving on the costs of the welfare system, at the expense of families and solidarity networks. Moreover, they show themselves as close to the vision of the family - and the woman -, which is defended by the religious authorities (Saraceno 2003). The result has been a sort of "coming back to traditionalism" in the midst of secularization (Sciolla 2015: 256-266), affecting both the cultural dimension and the practice of gender and family relationships.

Besides, the familistic torsion of social relationships weakens the spread of the beliefs and practices of a modern civic culture. On the one hand, and in a more general sense, this reduces the collective pressure to conform to the norms and cultural values and social solidarity and increases the convenience to behave selfishly (the so-called amoral familism: Banfield 1976, Tullio-Altan 2000). On the other hand, and with reference to the relationship between politicians and civil society, this seems to further weaken the sense of responsibility of the first towards the second.

The spread of the rhetoric and practice of familism is a reasonable choice for actors moving in a context marked not only by the exhaustion of a development pattern, with its opportunities for social inclusion and mobility, but also by the authoritarianism of religious institutions, the political class and the body of executives and public officials. The first kind of authoritarianism comes from the top-down nature of the internal processes of a religious

\footnotetext{
${ }^{10}$ Not surprisingly, the pay gap between graduates and undergraduates has decreased over time in Italy (Agnelli Foundation 2012).

${ }^{11}$ According to Ginsborg, «Familism is a specific relationship between family, civil society and the State within which the values and interests of the family are opposed to the other main parts of the human society. The Italian version of this relationship is not constant but neither is it a mirage. It is characterized by strongly cohesive family units, a relatively weak civil society and a deeply rooted lack of confidence in the central state» (1994: 78, my translation).
} 
denomination, the Catholic Church, which has in Italy an excess of legitimacy, for the presence of its world leader in the capital of the country. This exposes the State - that is, the national political class - to the risks associated with the challenge to its legitimacy by the Church and the duality of powers. The second and third type of authoritarianism, instead, comes from a deficit of legitimacy rooted in the processes of State formation and nation-building (Tullio-Altan 2000, see also Putnam 1993). The weakness of the fundamental core of the Italian State and the character of foreign invasion and civil war sometimes taken by the unification process (Tullio-Altan 2000, Ruffolo 2009) ${ }^{12}$ have a major role in this feature of the relationship between the Italian political class and the civil society.

All this resulted in a conflictual/cooperative relationship between the Church and the State. A relationship that still continues today, despite the processes of secularization in Italian society. After the unexpected collapse of the political system based on the hegemony of the Christian Democrats (19921994), the presence of Catholic politicians and the relationships with the Church hierarchy and Catholic organizations have been increasing across the political spectrum, in order to generate an exchange between (short-term) electoral support and benefits for the religious institutions and values (Garelli $2013)^{13}$. There are numerous examples: the exemption from property taxes, the discipline of conscientious objection to abortion, the public financial support to private schools, the resistance to same-sex marriage (Knill and Preidel 2015) and so on.

The social and cultural transformations and the protest movements of the 1960s and the 1970s produced deep changes in Italy. These processes allowed a real expansion of individual freedom of choice, despite the persisting power of the Church. At the same time, as noted by Tullio-Altan (2000), they also fostered a propensity to some sort of rebellious anarchism ${ }^{14}$.

Since the 1980s, the decline of antisystemic movements has reduced the attractiveness of forms of mobilization related to the political class of opposition and / or the anarchist rebellion. Nevertheless, it does not give new strength to the authoritarian mechanisms of consensus building, undermined by the spread of individualism and the second or late modernity (Giddens 1999) ${ }^{15}$.

\footnotetext{
${ }^{12}$ It seems appropriate to add that this feature of the process of formation of the Italian State has powerfully fueled the cleavage based on regional imbalances. This occurred first in the North, where a party - the Northern League - emerged around an identitarian claim that hides a widespread interest in the secession of the richest regions. In reaction to that, today a movement of opinion aiming to dispute the "Nordist" claims is becoming popular in the South (see Aprile 2010, Esposito 2013).

${ }^{13}$ In this article Garelli explores the relationship from the point of view of the religious institutions, highlighting the strategic importance of this change for the Church, in its attempt to preserve a wide political and cultural hegemony on Italian society.

14 The latter, according to Tullio-Altan, is the face taken by authoritarianism in the political and social behavior of those socially excluded, especially proletarianized intellectuals, though only as long as they remain excluded. See, for instance, the issue of trade unions micro disputes in the public sector and in State holdings, mentioned above.

${ }^{15}$ We should not forget, however, that the decline of collective subjectivities of early modern origin (mass parties, trade unions), acting as mediators between the "civil society" and the
} 
In this vacuum of legitimacy, the system of mass communications has acquired increasing relevance. Since the 1970s, the liberalization of this sector - especially in the field of television, the "first Italian cultural industry" resulted in the formation of a private television monopoly. In this context, the system has been producing the images that define the catalogue of the hopes and fears of the public, or at least those common to a public that is poorly educated and already immersed in a familistic / authoritarian system of values, which is the audience of commercial television (Abruzzese 1994, Panarari 2010, see also Ginsborg 1998: 207-215). By doing so, the system has gradually shaped a worldview that has greatly influenced the field of possible choices in the Italian political arena, particularly by restructuring the political scene around personalist conflicts centered on the figures of the leaders rather than about party programs and collective interests (Donovan 2015). Recently, however, the development of the Internet and social media has reopened the field of opportunities for political information and communication, thus fostering the emergence of new players. The latter can be local or national political movements, such as the 5 Star Movement (Mosca and Vaccari 2011).

It has been said that these structural changes in the political arena and in the communication system support the spread of a freedom of servants, subject to nothing but the will of the holder of power, and the dimming of the freedoms of citizens, subject to the same law for everyone - as that which occurred in the Italy of lordships and principalities (Viroli 2010). It must also be noted, however, that the proliferation of personal parties (Calise 1995) can be nothing but the reflection of a structural process - the "conflict of interest", namely the merger between a protected bourgeoisie and the political class facing the crisis of the development pattern - and a cultural orientation - the coupling of authoritarianism and familism, declinable in terms of servility, transformism, or rebellion for its own sake - that may stay with us for a long time.

\section{Concluding Remarks}

Before drawing the necessary conclusions from the previous analysis, it is worth recalling the limitations of the line of reasoning developed in this paper. My attempt to explain the crisis of the Italian pattern of development leaves in the background a set of variables that operate outside the Italian social formation but widely influence its path of change. The financialization of the economy, the globalization of production processes and markets, the spread of rhetoric and practice of neoliberalism in the ruling classes (Harvey 2005, 2010, Gallino 2007, 2011) are all global phenomena, which highlight the supranational character of the modern capitalist system. Moreover, many features of Italian social formation are common to other southern European societies (Sapelli 1996, Maddaloni 2008). Nevertheless, the Italian crisis shows peculiar features, which explain its particular gravity. No other European - even

political class, is a general phenomenon that involves new opportunities but also new risks for Western democracy (Crouch 2003). 
southern European - country apparently shows the peculiar combination of regional imbalances, inequalities rooted in corporatist-clientelist public policies, the political centrality of the Catholic Church and a monopolistic media system which so far has allowed for the preservation of the political class (despite the "revolutions" of 1992 and 2013) and business layers which derive their benefits from distorted public policies. The conceptual model developed in this paper suggests that the inability to reverse the trend showed by the Italian establishment (Gallino 2015: 131-155) can be explained by this configuration of factors.

In the second decade of the $21^{\text {st }}$ century, an Italian-style neoliberalism has emerged, in which profits are distributed in more and more limited ranges of "mice in the cheese" (Sylos Labini 1975, 1986), while the price, in Italy perhaps more than in other countries, is paid not only by the working class, but also by the middle classes. Nevertheless, the social conflicts derived from old and new splits - between the northern and the southern regions, among the middle and the working classes, between those who have social entitlements and those who have not, between religious expansionism and republican secularism - seem to hinder a common front in favor of a reform of the major institutional and social arrangements.

Despite this unpleasant picture, it seems reasonable to conclude with optimistic notes. The external constraint arising from the Italian membership of the European Union, although a major factor of financialization / globalization / privatization (Gallino 2015: 77-130), also has the effect of forcing part of Italian society to comply with standards typical of a developed country. As we have seen, the spread of the Internet and social networking is a factor militating in favor of proper information and "horizontal" communication, therefore supporting a new democratic participation. There is the legacy of social cohesion and political democracy given by the municipal self-government (Ginsborg 2010), shared in many parts of the country. Some economic sectors are increasingly exposed to international competition and they cannot easily relocate production and functions - such as for example tourism, but also and to a large degree, the system of the industrial districts. They appear, therefore, forced to sustain the modernization of the social, institutional and political structures. A significant proportion of civil servants is not resigned to a public image (and in part to a reality) of almost slackers (Ichino 2006). Finally, we must not forget the cultural growth of broad social layers of the Italian population, nor the new energies that immigration can provide to economic, social and political innovation (Montagna 2012).

\section{Acknowledgments}

A previous version of this paper was published in Maddaloni (2012). I am grateful to my friends and colleagues - especially Luca Bifulco and Francesco Pirone (University of Naples "Federico II") - for their useful comments. 


\section{References}

Abruzzese A (1994) Elogio del tempo nuovo. Perché Berlusconi ha vinto [Eulogy of the new time. Why Berlusconi won]. Genova: Costa e Nolan.

Agnelli Foundation (2012) I nuovi laureati. La riforma del $3+2$ alla prova del mercato del lavoro [The new graduates. The reform of the $3+2$ and the test of the labor market]. Bari: Laterza.

Aprile P (2010) Terroni. Tutto quello che è stato fatto perché gli Italiani del Sud diventassero "meridionali" [Terroni. All that has been done to ensure that South Italians became "southerners"]. Milano: Rizzoli.

Ascoli U (Ed) (1984) Welfare state all'italiana [Welfare state, Italian-style]. Bari: Laterza.

Ascoli U, Pavolini E (2012) Ombre rosse. Il sistema di welfare italiano dopo venti anni di riforme [Red Shadows. The Italian welfare system after twenty years of reforms]. Stato e mercato 96.

Bagnasco A (1977) Tre Italie. La problematica territoriale nello sviluppo italiano [Three Italies. The territorial issue of Italian development]. Bologna: Il mulino.

Bagnasco A (1996) L'Italia in tempi di cambiamento politico [Italy in times of political change]. Bologna: Il mulino.

Bagnasco A (2015) Classi, ceti, individui: 1961-2011 [Classes, layers, individuals: 1961-2011]. In M Dogliani, S Scamuzzi (Eds) L'Italia dopo il 1961. La grande trasformazione. Bologna: Il mulino.

Banfield EC (1976) Le basi morali di una società arretrata [The moral basis of a backward society]. Bologna: Il mulino.

Barbagallo F (1994) La modernità squilibrata del Mezzogiorno d'Italia [The unbalanced modernity of the Southern Italy]. Torino Einaudi.

Bertoli G, Resciniti R (Eds) (2012) International marketing and the country of origin effect. The global impact of 'Made in Italy'. Cheltenham-Northampton: Edward Elgar.

Bianco M, Giacomelli S, Rossi S (2012) L'impresa familiare. Un'anomalia italiana? [Family firm: an Italian anomaly?] Il mulino 1.

Biorcio R (2015a) Il populismo nella politica italiana. Da Bossi a Berlusconi, da Grillo a Renzi [Populism in Italian politics. From Bossi to Berlusconi, from Grillo to Renzi]. Sesto San Giovanni: Mimesis.

Biorcio R (Ed) (2015b) Gli attivisti del Movimento 5 Stelle. Dal web al territorio [The activists of the 5 Stars Movement. From the web to the territory]. Milano: FrancoAngeli.

Biorcio R, Natale R (2013) Politica a 5 stelle. Idee, storia e strategie del movimento di Beppe Grillo [Five star politics. Ideas, history and strategies of Beppe Grillo's movement]. Milano: Feltrinelli.

Bologna S, Fumagalli A (Eds) (1997) Il lavoro autonomo di seconda generazione. Scenari del postfordismo in Italia [The second generation of self-employment. Scenarios of post-Fordism in Italy]. Milano: Feltrinelli.

Bonifazi C (2013) Mobili per forza. Spostamenti di popolazione nell'Italia della crisi [Induced migrants. Population movements in the Italy of crisis]. Il mulino 5.

Bonomi A, Rullani E (2005) Il capitalismo personale. Vite al lavoro [Personal capitalism. Lives at work]. Torino: Einaudi.

Bordignon F (2014) Matteo Renzi: A "Leftist Berlusconi" for the Italian Democratic Party? South European Society and Politics 19(1):1-23.

Bubbico D, Morlicchio E, Rebeggiani E (2013) Su e giù per l'Italia. La ripresa delle 
migrazioni interne e le trasformazioni del mercato del lavoro [Up and down across Italy. The recovery of internal migration and the changing job market]. Milano: FrancoAngeli.

Bull M (2012) The Italian transition that never was. Modern Italy 17(1).

Calise M (1995) Il partito personale [The personal party]. Bari: Laterza.

Ciccarone P, Saltari E (2015) Cyclical downturn or structural disease? The decline of the Italian economy in the last twenty years. Journal of Modern Italian Studies 2.

Ciliberto M (2015) Le forme della partecipazione: dai partiti alla casta [The forms of participation: from political parties to the caste]. In M Dogliani, S Scamuzzi (Eds) L'Italia dopo il 1961. La grande trasformazione. Bologna: Il mulino.

CNEL (2014) Working poor. Un'analisi sui lavoratori a bassa remunerazione dopo la crisi [Working poor. The low-paid workers after the crisis]. Roma: CNEL.

Colloca P (2015) Le conseguenze della crisi economica sugli atteggiamenti civici in Italia: una recessione silenziosa? [The consequences of the economic crisis on civic attitudes in Italy: a silent recession?]. Polis 2: 251 - 278.

Crouch C (2003) Postdemocrazia [Post-Democracy]. Bari: Laterza.

Crouch C (2012) Il declino delle relazioni industriali nell'odierno capitalismo [The decline in industrial relations in today's capitalism]. Stato e mercato 94.

De Mauro T (2004) La cultura degli Italiani [The culture of Italians]. F. Erbani (Ed). Bari: Laterza.

Dente B (Ed) (1990) Le politiche pubbliche in Italia [Public policies in Italy]. Bologna: Il mulino.

Donovan M (2015) Berlusconi' s impact and legacy: political parties and the party system. Modern Italy 20(1): 11-24.

Esposito M (2013) Separiamoci [Let us part]. Milano: Magenes.

Eurostat (2014) Taxation trends in the European Union. Data for the EU member states, Iceland and Norway. Bruxelles: Eurostat.

Ferrera M (1984) Il welfare state in Italia [The welfare state in Italy]. Bologna: Il mulino.

Galli G (1986) Il partito armato. Gli 'anni di piombo' in Italia 1968-1986 [The armed party. The "years of lead" in Italy 1968-1986]. Milano: Rizzoli.

Gallino L (2003) La scomparsa dell'Italia industriale [The vanishing of industrial Italy]. Torino: Einaudi.

Gallino L (2006) Italia in frantumi [Shattered Italy]. Bari: Laterza.

Gallino L (2007) Globalizzazione e disuguaglianze [Globalization and inequalities]. Bari: Laterza.

Gallino L (2011) Finanzcapitalismo. La civiltà del denaro in crisi [Finanzkapitalismus. The civilization of the money in crisis]. Torino: Einaudi.

Gallino L (2015) Il denaro, il debito e la doppia crisi spiegati ai nostri nipoti [Money, debt and the double crisis explained to our grandchildren]. Torino: Einaudi.

Garelli F (2013) Catholiques, politique et culture. Le cas italien [Catholics, politics and culture. The italian case]. Social Compass 3.

Gerschenkron A (1965) Il problema storico dell'arretratezza economica [Economic Backwardness in Historical Perspective]. Torino: Einaudi.

Giddens A (1999) Identità e società moderna [Modernity and self-identity: Self and society in the late modern age]. Napoli: Ipermedium.

Ginsborg P (1989) Storia d'Italia dal dopoguerra ad oggi. Società e politica 19431988 [A History of Contemporary Italy: Society and Politics, 1943-1988]. Torino: Einaudi.

Ginsborg P (1994) Familismo [Familism]. In P Ginsborg (Ed) Stato dell'Italia. Milano: Il saggiatore. 
Ginsborg P (1998) L'Italia del tempo presente. Famiglia, società civile, Stato 19801996, (Modern day Italy. Family, civil society, State 1980-1996. Torino: Einaudi.

Ginsborg P (2010) Salviamo l'Italia [Let's save Italy]. Torino: Einaudi.

Gorrieri E (1972) La giungla retributiva [The jungle of salaries]. Bologna: Il mulino.

Graziano L, Tarrow S (Eds) (1979) La crisi italiana [The Italian crisis]. Torino: Einaudi.

Harvey D (2005) A brief history of neoliberalism. Oxford: Oxford University Press.

Harvey D (2010) The enigma of capital and the crises of capitalism. Oxford: Oxford University Press.

Hirsch F (1977) Limiti sociali allo sviluppo [Social Limits to Growth]. Milano: Bompiani.

Ichino P (2005) A che cosa serve il sindacato? Le follie di un sistema bloccato e la scommessa contro il declino [What good is the union? The follies of a frozen system and the bet against the decline]. Milano: Mondadori.

Ichino P (2006) I nullafacenti. Perché e come reagire alla più grave ingiustizia della nostra amministrazione pubblica [The slakers. Why and how to react to the most serious injustice in our public administration]. Milano: Mondadori.

Istat (1999) Le organizzazioni di volontariato in Italia. Struttura, risorse, attività, [Voluntary organizations in Italy. Structure, resources, activity]. Roma: Istat.

Karvonen L, Kuhnle S (Eds) (2001) Party systems and voter alignments revisited. London-New York: Routledge.

Knill C, Preidel C (2015) Institutional opportunity structures and the Catholic Church: explaining variation in the regulation of same-sex partnerships in Ireland and Italy. Journal of European Public Policy 22(3): 374-390.

Lasch Ch (1979) The culture of narcissism. American life in an age of diminishing expectations. New York - London: Norton \& Company.

Lazar M, Matard-Bonucci MA (2010) L'Italie des années de plomb. Le terrorisme entre histoire et mémoire [Italy in the years of lead. Terrorism between history and memory]. Paris: Autrement.

Lipset SM, Rokkan S (1967) Cleavage Structures, Party Systems and Voter Alignments: An Introduction. In SM Lipset, S Rokkan (Eds) Party systems and voter alignments: cross-national perspectives. New York: The Free Press.

Livadiotti S (2008) L'altra casta. Privilegi, carriere, misfatti e fatturati da multinazionale. L'inchiesta sul sindacato [The other caste. Privileges, careers, misdeeds and multinational-like budgets. An inquiry on unions]. Milano: Bompiani.

Maddaloni D (1993) Fattori di regolazione delle domande sociali e processi di mutamento: alcune osservazioni sul ruolo dell'opposizione di sinistra nel Mezzogiorno [Factors of regulation of social demands and processes of change: some observations on the role of the left opposition in the South]. Sociologia e ricerca sociale 41.

Maddaloni D (1998) Deregolazione del mercato del lavoro e disoccupazione: un confronto internazionale [Labor market deregulation and unemploment: an international comparison]. In A Barbieri et al. (Eds) Lo Stato sociale in Italia. Rapporto Iridiss-Cnr 1998. Roma: Donzelli.

Maddaloni D (2000) L'economia della partecipazione tra modelli di società e politica per l'occupazione [Share economy: between social models and employment policy]. Economia e lavoro 1.

Maddaloni D (2003) Una scelta ragionevole in tempi complicati. Note sull'economia politica delle riforme nell'epoca della crisi dello sviluppo e del welfare [A reasonable choice in hard times. Notes on the political economy of reforms in the 
age of the crisis of welfare and development]. Quaderni di sociologia 32.

Maddaloni D (2004) Il mercato e la politica del lavoro nella stagione delle riforme [Labor market and employment policy in the age of reforms]. In E Pugliese (Ed) Lo Stato sociale in Italia. Un decennio di riforme. Roma: Donzelli.

Maddaloni D (2008) Lavoro e welfare nell'Europa mediterranea. Successi e contraddizioni di uno sviluppo dualistico [Work and welfare in Mediterranean Europe. Achievements and contradictions of a dualistic development]. In G Ponzini, G Pugliese (Eds) Un sistema di welfare mediterraneo. Rapporto IrppsCnr sullo Stato sociale in Italia 2007-2008. Roma: Donzelli.

Maddaloni D (2009) Se l'Italia si frantuma dove va il Mezzogiorno? Riflessioni nella prospettiva della political economy [If Italy brokens, where does the South go? Reflections in a political economy perspective]. L'acropoli 2: 128- 157.

Maddaloni D (2012) Italia. In D Maddaloni (Ed) Il mondo contemporaneo. Un lessico sociologico. Napoli: IperMedium Libri.

Mania R (2013) Il dramma del lavoro e le responsabilità degli imprenditori [The tragedy of the work and the employers responsibilities]. Il mulino 6.

McCarthy P (1995) The crisis of the Italian state. From the origins of the cold war to the fall of Berlusconi and beyond. London: MacMillan.

Montagna N (2012) Labor, citizenship and subjectivity: Migrant struggles within the Italian crisis. Social Justice 39(1).

Mosca G (1994) La classe politica [The political class]. N Bobbio (Ed). Bari: Laterza.

Mosca L, Vaccari C (Eds) (2011) Nuovi media, nuova politica? Partecipazione e mobilitazione online da MoveOn al Movimento 5 Stelle [New media, new politics? Online participation and mobilization, from MoveOn to the 5 Star Movement]. Milano FrancoAngeli.

Mosco V (2009) The political economy of communication. London: Sage.

Nicoletta V (2013) Crisi e stratificazione sociale. Come cambiano le disuguaglianze sociali in Italia [Crisis and social stratification. How social inequalities change in Italy]. Sociologia del lavoro 131.

Openpolis Organization (2011) Camere Aperte 2011. Rapporto sull'attività del Parlamento [Open Parliament 2011. A Report on parliamentary activity]. Retrieved from http://bit.ly/1W2ihKt.

Paci M (1982) La struttura sociale italiana. Costanti storiche e trasformazioni recenti [The Italian social structure. Historical heritage and recent shifts]. Bologna: Il mulino.

Paci M (1992) Il mutamento della struttura sociale italiana [Change in the Italian social structure]. Bologna: Il mulino.

Panarari M (2010) L'egemonia sottoculturale. L'Italia da Gramsci al gossip [The subcultural hegemony. Italy from Gramsci to gossip]. Torino: Einaudi.

Pini P, Leonardi M (2015) Sulla riforma del mercato del lavoro [On labor market reform]. Il mulino 1.

Piselli F (1981) Parentela ed emigrazione. Mutamenti e continuità in una comunità calabrese [Parenthood and emigration. Changes and continuities in a Calabrian community]. Torino: Einaudi.

Pizzorno A (1980) I soggetti del pluralismo. Classi partiti sindacati [The actors of pluralism. Classes parties unions]. Bologna: Il mulino.

Pugliese E (2006) L'Italia tra migrazioni internazionali e migrazioni interne [Italy between international and internal migrations]. Bologna: Il mulino.

Pugliese E (Ed) (2004) Lo Stato sociale in Italia. Un decennio di riforme [Welfare State in Italy. A decade of reforms]. Roma: Donzelli.

Putnam RD (1993) La tradizione civica delle regioni italiane [Making Democracy 
Work: Civic Traditions in Modern Italy]. Milano: Mondadori.

Ranci C (Ed) (2012) Partite IVA. Il lavoro autonomo nella crisi italiana [VAT numbers. Self-employment in the Italian crisis]. Bologna: Il mulino.

Rizzo S, Stella GA (2008) La deriva. Perché l'Italia rischia il naufragio [The drift. Why Italy risks a shipwreck]. Milano: Rizzoli.

Ruffolo G (2009) Un Paese troppo lungo. L'unità nazionale in pericolo [A country too long. National unity in danger]. Torino: Einaudi.

Sabbadini LL (2012) Social and demographic change in italy. In F Maggino, G Nuvolati (Eds) Quality of Life in Italy. Research and Reflections. DordrechtHeidelberg-New York-London: Springer.

Salvini A (2012) Volontariato come interazione. Come cambia la solidarietà organizzata in Italia [Volunteering as interaction. How organized solidarity changes in Italy]. Pisa University Press.

Santoro M (2015) Formare giovani e regalarli all'estero [To train young people and give them away abroad]. Il mulino 3.

Sapelli G (1996) L'Europa del Sud dopo il 1945. Tradizione e modernità in Portogallo, Spagna, Italia, Grecia, Turchia [Southern Europe Since 1945: tradition and modernity in Portugal, Spain, Italy, Greece and Turkey]. Soveria Mannelli: Rubbettino.

Saraceno C (2003) Mutamenti della famiglia e politiche sociali in Italia [Family changes and social policy in Italy]. Bologna: Il mulino.

Saraceno C (2015) Famiglia, genere e lavoro [Family, gender and work]. M Dogliani, S Scamuzzi (Eds) L'Italia dopo il 1961. La grande trasformazione. Bologna: Il mulino.

Schiavone A (1998) Italiani senza Italia. Storia e identità [Italians without Italy. History and identity]. Torino: Einaudi.

Schizzerotto A (Ed) (2002) Vite ineguali. Diseguaglianze e corsi di vita nell'Italia contemporanea [Unequal lives. Inequalities and lifecourses in contemporary Italy]. Bologna: Il mulino.

Sciolla L (2012) Il paradosso di un Paese poco istruito [The paradox of an uneducated country]. Il mulino 6.

Sciolla L (2015) Il tradizionalismo senza identità degli Italiani [Italian traditionalism without identity]. In M Dogliani, S Scamuzzi (Eds) L'Italia dopo il 1961. La grande trasformazione. Bologna: Il mulino.

Secondulfo D (2013) Consumate strategie, le famiglie italiane a fronte della crisi economica e della contrazione del potere di acquisto [Consumed strategies, Italian families faced with the economic crisis and the decline in purchasing power]. Sociologia del lavoro 132.

Sklair L (2001) The transnational capitalist class. Oxford: Wiley-Blackwell.

Staniland M (1985) What is political economy? A study of social theory and underdevelopment. USA: Yale University Press.

Stella GA, Rizzo S (2007) La casta. Così i politici italiani sono diventati intoccabili [The caste. How Italian politicians became untouchables]. Milano: Rizzoli.

SVIMEZ (2015) Rapporto SVIMEZ 2015 sull'economia del Mezzogiorno [SVIMEZ Report on Southern Italy's economy]. Bologna: Il mulino.

Sylos Labini P (1975) Saggio sulle classi sociali [An essay on social classes]. Bari: Laterza.

Sylos Labini P (1986) Le classi sociali negli anni '80 [Social classes in the Eighties]. Bari: Laterza.

Toscano MA (Ed) (2007) Homo instabilis. Sociologia della precarietà [Homo instabilis. A sociology of precariousness]. Milano: Jaca Book. 
Trigilia C (1992) Sviluppo senza autonomia. Effetti perversi delle politiche per il Mezzogiorno [Development without autonomy. Perverse effects of the policies for the South]. Bologna: Il mulino.

Trigilia C (Ed) (1995) Cultura e sviluppo. L'associazionismo nel Mezzogiorno [Culture and development. Associations in the South]. Roma: Donzelli.

Tullio-Altan C (2000) La nostra Italia. Clientelismo, trasformismo e ribellismo dall'Unità al 2000 [Our Italy. Clientelism, transformism and rebelliousness from the Unity to 2000]. Milano: EGEA.

Vannucci A (2012) Un nuovo paradigma contro la corruzione [A new paradigm against corruption]. Il mulino 3.

Vannucci A (2013) La corruzione in Italia: cause, dimensioni, effetti [Corruption in Italy: Causes, characters, consequences]. In BG Mattarella, M Pellissero (Eds) La legge anticorruzione. Prevenzione e repressione della corruzione. Torino: Giappichelli.

Viesti G (2009) Nord-Sud: l'eterna questione [North-South: the eternal debate]. Il mulino 5.

Viroli M (2010) La libertà dei servi [The freedom of slaves]. Bari: Laterza.

Vitale A (1998) I paradigmi dello sviluppo. Le teorie della dipendenza, della regolazione e dell'economia-mondo [Development paradigms. The theories of dependence, regulation and world-economy]. Soveria Mannelli: Rubbettino. 
